\title{
HARMONISASI PRINSIP PERLINDUNGAN MEREK TERKENAL KONVENSI PARIS DALAM UNDANG - UNDANG NOMOR 20 TAHUN 2016 TENTANG MEREK DAN INDIKASI GEOGRAFIS
}

\section{(Harmonization Of Protection Principles Famous Brand In Paris Convention Law - Law Number 20 Year 2016 Concerning Brand And Geographic Indication)}

\author{
Maolana Alfarizi, Mas Anienda Tien F \\ Universtas Pembangunan Nasional "Veteran" Jawa Timur \\ Jl. Rungkut Madya No.1, Gn. Anyar, Kec. Gn. Anyar, Kota SBY, Jawa Timur 60294 \\ 082259445143 \\ E-mail : masanienda.ih@upnjatim.ac.id
}

\begin{abstract}
Abstrak
Artikel ini membahas prinsip-prinsip perlindungan hukum merek terkenal berdasarkan Konvensi Paris dan penerapannya setelah diundangkannya UUMerek dan Indikasi Geografis Nomor 20 Tahun 2016 konsep landasan yuridis serta konstitusi yang berkaitan terhadap topik tulisan ini. dalam hal ini konvensi paris yang memuat prinsipprinsip perlindungan hukum merek terkenal telah diakomodasi dengan baik oleh pemerintah Indonesia melalui legislasi nasional dengan Undang-Undang Nomor 20 Tahun 2016 tentang Merek dan Indikasi Geografis, yang menjelaskan melalui beberapa pasal dari pendaftaran maupun sampai penyelesaian sengketa serta penerapan perlindungan hukumnya dalam beberapa kasus sengketa merek terkenal juga sudah terlaksana menurut kaidah legal merek terkenal yang ada dalam konvensi paris.
\end{abstract}

Kata Kunci: Prinsip, Perlindungan Hukum, Merek Terkenal

\section{PENDAHULUAN}

$\begin{array}{rcr}\text { Setiap } & \text { bisnis atau perusahaan yang } \\ \text { memproduksi barang atau jasa untuk }\end{array}$ mempromosikan bisnis dan ekonominya akan menggunakan banyak strategi, salah satunya adalah branding. Dari segi fungsinya, peran sebuah merek adalah memandang identitas sebagai produk atau produk atau jasa terpenting yang membedakannya dengan produk yang diproduksi oleh perusahaan. Tidak terbayangkan bahwa produk atau jasa dapat dijual tanpa menggunakan merek dagang, tentunya sulit bagi konsumen untuk menemukan ciri khas tiap produsen. Komunikasi antara produsen dan konsumen sebagai jaminan individualitas, dan reputasi produk atau layanan berkontribusi pada hasil pasar perusahaan. Perlindungan hukum terhadap merek diperlukan karena merek memiliki hak moral dan ekonomi, yaitu barang dan jasa yang sangat berharga yang dapat membuktikan kualitas barang yang diperdagangkan tertentu. Untuk memperoleh perlindungan hukum, merek harus didaftarkan. Pendaftaran merek juga cocok sebagai dasar untuk menolak merek dagang yang kira-kira atau secara substansial sama dengan yang digunakan oleh orang lain atau perusahaan untuk penggunaan barang atau jasa serupa secara jahat. (Hasibuan, 2003).

Dalam penelitian ini, penulis menganalisis penerapan prinsip-prinsip perlindungan hukum "Paris Convention for the Protection of Industrial Property" (Paris Convention) untuk merek-merek terkenal. Secara khusus, Pasal 2 dan 6 mengatur tentang prinsip-prinsip perlakuan nasional, prioritas dan Ketentuan umum. Sangat penting untuk menyetujui dan menerapkan peraturan perlindungan legal untuk merek terkenal skala nasional, karena menjadi landasan untuk merek terkenal yang tidak mendaftar di dalam negeri atau internasional, dan mencegah plagiarisme dan menciptakan keinginan baik-penulis terkenal merek akan menganalisis apakah prinsip-prinsip tersebut termasuk dalam UU No. 20 Tahun 2016. Selain analisis putusan pengadilan, putusan pengadilan Indonesia juga dipertimbangkan, Putusan No. 119 PK/Pdt.SusHKI/2017 melibatkan sengketa merek yang diakui. Dengan berlakunya "UU Merek", hal ini menimbulkan perlindungan hukum terhadap merekmerek terkenal. 


\section{Latar Belakang}

Perlunya perlindungan hukum terhadap merek karena mempunyai hak moral dan hak ekonomi yang sangat bernilai atas suatu barang dan jasa yang menunjukkan kualitas barang tertentu dalam perdagangan. Untuk mendapatkan perlindungan hukum, suatu merek harus didaftarkan. Dalam dinamika dan realita saat ini, banyak sekali terjadi sengketa dalam bidang merek. Munculnya suatu merek baru yang kemudian eksis di tengah-tengah masyarakat dengan meniru atau menjiplak secara keseluruhan atau sama pada pokoknya dengan merek terkenal yang telah didaftarkan dan digunakan oleh perusahaan lain dianggap sebagai bencana bagi perusahaan. Maka kehadiran perangkat hukum yang didalamnya memuat prinsip-prinsip perlindungan hukum mampu melindungi merek terkenal memang sangat dibutuhkan oleh setiap badan usaha

\section{Rumusan Masalah}

1. Apakah prinsip - prinsip perlindungan merek terkenal dalam konvensi paris telah diakomodasi Undang - Undang Nomor 20 Tahun 2016 tentang Merek dan Indikasi Geografis ?

2. Bagaimana penerapan perlindungan merek terkenal setelah berlakunya Undang - Undang Nomor 20 Tahun 2016 tentang Merek dan Indikasi Geografis?

\section{Tujuan}

1. Untuk mengetahui prinsip - prinsip perlindungan merek terkenal dalam konvensi paris telah diakomodasi Undang-Undang Nomor 20 tahun 2016 tentang Merek dan Indikasi Geografis.

2. Untuk mengetahui penerapan perlindungan merek - merek terkenal setelah berlakunya Undang-Undang Nomor 20 tahun 2016 tentang Merek dan Indikasi Geografis dalam Putusan Pengadilan di Indonesia.

\section{Metode Penelitian}

Memuat cara dan langkah dalam kegiatan untuk menjawab permasalahan penelitian. Terdiri dari

\section{Pendekatan}

Pendekatan dalam penelitian ini yaitu penelitian kualitatif. Penelitian ini menggunakan metode yuridis-normatif, merupakan metode yang dilakukan berdasarkan bahan hukum utama dengan cara menelaah teori-teori, konsep-konsep, asas-asas hukum serta peraturan perundang-undangan yang berhubungan dengan penelitian ini

\section{Metode Pengumpulan Data}

Data penelitian diperoleh dari kegiatan Library reseach, dari bahan hukum primer maupun sekunder, berupa putusan-putusan, perundang-undangan terkait, serta buku-buku, Jurnal, pendapat para ahli, serta bahan lain yang relevan dengan penelitian.

\section{Teknik Analisa Data}

Adapun analisa data yang dilakukan dalam penelitian ini adalah secara kualitatif. Data yang diperoleh diolah dengan metode kualitatif, yaitu dinyatakan oleh sumber, baik secara lisan maupun tulisan yang dipelajari sebagai sesuatu yang utuh, yaitu dengan menggabungkan antara permasalahan dan data yang diperoleh untuk tercapainya kesimpulan tertentu sehingga diperoleh hasil yang signifikan dan ilmiah.

\section{PEMBAHASAN (font 12pt, bold, capital)}

Di Indonesia, peraturan merek diatur dalam Undang-Undang Merek No. 15 Tahun 2001 dan diubah dengan Undang-Undang Nomor 20 Tahun 2016 tentang Merek dan Indikasi Geografis. yang meratifikasi dari konvensi paris pada tahun 1979. Yang akar atau basis dari aturan ini terdapat pada Article 5 (2) Paris Conventions:

"Use of trademark by the proprietor in a from differing in elements which do not alter the distinctive character of the mark in the from in wich it was registered in one of the countries of the union shall not entail invalidation of registration and shall not disminish the protection granted to the mark".

Terjemahan bebas mengacu pada penggunaan merek dagang pemilik dalam bentuk dengan elemen lain, tetapi tidak menghilangkan kekhasan metode pendaftaran merek di negaranegara yang berpartisipasi dalam konvensi, juga tidak akan menyebabkan pembatalannya. Dan tidak akan menghilangkan perlindungan yang diberikan sebagai merek dagang. (Jened, 2000).

Dalam penelitian ini, penulis akan menganalisa penerapan prinsip "Paris Convention for the Protection of Industrial Property (Konvensi Paris)" Khususnya pada Article 2 \& 6 yang diantaranya terdapat prinsip national treatment, hak prioritas, dan ketentuan-ketentuan umum. Prinsipprinsip ini penting untuk disetujui dan diterapkan dalam pengawasan Indonesia terhadap perlindungan hukum merek-merek terkenal, karena memberikan perlindungan hukum bagi merek-merek terkenal yang tidak terdaftar di dalam negeri dan internasional, dan melindungi mereka dari menjiplak merek terkenal. merek untuk dirakit. Prinsip-prinsip tersebut telah dimasukkan ke dalam UU No. 20 Tahun 2016 dan Keputusan No. 119 PK/Pdt tentang Merek Dagang dan Indikasi Geografis. / Analisis merek dagang yang disengketakan dan keputusan pengadilan pada tahun 2017 menghasilkan merek dagang terkenal yang dilindungi oleh hukum karena undang-undang merek dagang yang efektif.

PRINSIP - PRINSIP PERLINDUNGAN MERK TERKENAL KONVENSI PARIS DI AKOMODASI UNDANG - UNDANG NOMOR 20 TAHUN 2016

1. Prinsip Perlindungan Merek Terkenal Menurut Konvensi Paris

Berikut ini adalah beberapa prinsip - prinsipnya yaitu :

a. National Treatment 
Salah satu prinsip terpenting dimana pelayanan yang sama seluruhnya terhadap WNA dan warga negaranya. Asas perlakuan atau asimilasi nasional (assimilation principle) adalah warga negara peserta diakui serta memperoleh hak yang serupa antara warga negara tempat merek terdaftar. Asas perlakuan nasional berlaku bagi setiap negara anggota, artinya warga negara dari suatu negara peserta Konvensi Paris harus menikmati perlindungan hukum yang adil di negaranya sendiri, sehingga warga negara tersebut memperoleh keadilan sebagai warga negara anggota tersebut.

Adapun perlindungan merek terkenal di dunia, Pasal 6bis Konvensi Paris akan berlaku, yang kemudian dimasukkan ke dalam Perjanjian TRIPS melalui Pasal 16(2), dan diadopsi pula oleh Penjelasan Pasal 21 ayat (1) huruf b Undang-Undang Merek Nomor 20 Tahun 2016. Selengkapnya berbunyi sebagai berikut:

"Aricle 6 bis of Paris Convention (1967) shall apply, mutatis mutandis, to service. In determining whether a trade mark is well-known member state shall take account of the knowladge of the knowladge of the trademark in relevant sectors of the public, including knowladge in the members concerne which has been obtained as a result of the promotion of the trademark"

Sebagai Negara yang telah menandatangai Konvensi Paris dan persetujuan tentang "Agreement on Trade Related Aspect of Intellectual Property Rights, Including Trade in Company Goods/TRIPs", Indonesia harus mempertahankan merek ternama. Definisi merek terkenal masih kontroversial. Tes yang digunakan masih belum jelas. Batasan merek sebagai merek terkenal tidak terbatas pada merek asing pihak ketiga, tetapi juga mencakup merek lokal pengusaha nasional yang telah berhasil berekspansi secara internasional. Fakta bahwa suatu merek terdaftar sebagai merek terkenal tidak hanya berdasarkan Pasal 6bis Konvensi Paris, tetapi juga berdasarkan undang-undang merek yang berlaku atau interpretasi hakim dalam putusannya.

\section{b. Hak Prioritas (Right of Priority)}

Prioritas perlindungan hak kekayaan intelektual hanya diperuntukkan bagi negara-negara anggota Konvensi Paris atau perjanjian pembentukan Organisasi Perdagangan Dunia. perjalanan. Ketentuan utama Konvensi Paris tentang prioritas (Purwaningsih, 2005)

Dengan menggunakan prioritas berdasarkan pernyataan pemohon pertama di negara anggota, pemohon dapat mengajukan permohonan perlindungan dalam jangka waktu tertentu selama 6 atau 12 bulan, sama seperti jika ia mendaftar pada hari yang sama dengan permohonan pertama. Negara-negara anggota beroperasi sesuai dengan prinsip independensi, yang berarti bahwa ketentuan HKI di satu negara tidak memerlukan ketentuan hak kekayaan intelektual di negara lain. Tanggal penerimaan permohonan pendaftaran atau tanggal pengajuan merupakan inti dari konsep prioritas terkait waktu pendaftaran, yaitu pendaftaran sebelum acara yang sebenarnya. Artinya ada prioritas berdasarkan permintaan. Itu tidak terjadi secara otomatis. Arti dari konsep prioritas terletak pada penggunaan dan definisi tanggal penerimaan yang berasimilasi dengan tanggal penerimaan di negara asal. Ini tentu saja terlihat sama dalam arti sebuah alasan, bukannya benar. Jadi ini cerita fiktif. Atau menyarankan (Sufiarina, 2012).

Ini berarti bahwa berdasarkan pendaftaran pertama di satu negara peserta, pendaftar dapat mengajukan permohonan perlindungan di negara peserta lain dalam waktu 6 bulan, yang dihitung sebagai pendaftaran pada hari yang sama dengan pendaftaran pertama. Dengan kata lain, selama periode ini, pendaftaran berikutnya memiliki prioritas di atas permohonan orang lain untuk penemuan, merek dagang, atau desain yang sama. Prioritas mengharuskan orang asing untuk tidak didiskriminasi ketika mendaftarkan hak kekayaan intelektual di negara yang mengadakan kontrak. Perjanjian Paris atau perjanjian pembentukan Organisasi Perdagangan Dunia.

Selain menjadi pihak dalam Konvensi Paris, Indonesia juga telah menandatangani sejumlah perjanjian, termasuk perjanjian TRIPS terbaru (trade-related Intellectual Property Rights) yang merupakan perjanjian terlengkap. Di bidang kekayaan intelektual, semua negara anggota WTO terikat oleh Perjanjian TRIPS. (Hadi, 2003).

Perlindungan hukum terhadap beberapa merek terkenal tertuang terkaitPasal 16 ayat 1- 3 Perjanjian TRIPS. Untuk barang atau jasa serupa yang tercantum dalam Pasal 16.1 Perjanjian TRIPS, pemegang merek dagang terkenal memiliki hak eksklusif atas merek dagang, implikasinya pemilik merek dagang, merek terkenal dilindungi oleh hukum; tanpa persetujuan pemilik merek dagang, pihak lain tidak diperbolehkan menggunakan merek terkenal untuk barang atau jasa tersebut. Pasal 6bis Konvensi Paris dialihkan ke Pasal 16(2) dan (3) kontrak perjalanan. Pasal 16 Paragraf 2 Perjalanan Kontrak ini memberikan perlindungan hukum untuk merek jasa terkenal dan 
memberikan perlindungan hukum sesuai dengan Pasal 6bis Konvensi Paris. Kesadaran merek yang relevan di sektor publik, termasuk pemahaman anggota tentang apa yang akan mereka peroleh dengan mempromosikan merek. (3) Kontrak perjalanan juga merupakan Pasal 6bis Konvensi Paris. Pasal ini mengatur bahwa perlindungan merek terkenal tidak hanya mencakup barang sejenis, tetapi juga barang yang berbeda. Namun, definisi berbagai produk dalam artikel ini tidak menunjukkan apakah mereka termasuk kategori produk yang berbeda. (Nurul Intan Sari, 2015).

2. Perlindungan Merek Terkenal Dalam Undang - Undang Republik Indonesia Nomor 20 Tahun 2016 Tentang Merek dan Indikasi Geografis

Berikut ini beberapa pasal dalam Undang-Undang Nomor 20 Tahun 2016 tentang Merek dan Indikasi Geografis yang memuat prinsip perlindungan hukum merek terkenal dalam Konvensi Paris :

\section{Hak Prioritas}

a. Pasal 9 dan 10 Undang-Undang No. 20 Tahun 2016 tentang Merek dan Indikasi Geografis

Pasal 9 dan 10 mengatur bahwa permohonan penggunaan prioritas harus diajukan di negara lain yang menjadi anggota Konvensi Paris dalam kurun 6 (enam) bulan tertanggal diterima permohonannya pendaftaran merek yang pertama. Terkait Properti Industri dalam "Konvensi Paris untuk Perlindungan Properti Industri" dimana pihak dalam perjanjian yang membentuk Organisasi Perdagangan Dunia. "Selain harus memenuhi persyaratan yang disebutkan dalam pernyataan prioritas, juga harus disertai dengan surat keterangan permohonan pendaftaran merek yang mendapat prioritas. Suratnya kemudian dialihbahasakan bahasa Indonesia. Dimana hak untuk mengajukan permohonan menggunakan prioritas yang diberikan berakhir Jika persyaratan ini tidak terpenuhi dalam waktu 3 (tiga) bulan ke depan, aplikasi tetap diproses, tetapi prioritas tidak digunakan.

b. Pasal 35 Undang-Undang No. 20 Tahun 2016 tentang Merek dan Indikasi Geografis

Di dalam pasal-pasal ini memuat mengenai pengaturan Hak Prioritas yang diakomodasi dari prinsip perlindungan hukum merek terkenal yang terdapat dalam Konvensi Paris dalam pasal 6 bis yang sudah sejalan memenuhi kriteria perlindungan hukum merek terkenal bagi negara anggota Konvensi Paris tentang Pelindungan Kekayaan Industri (Paris Convention for the Protection of Industrial Property)

2. National Treatment

1. Pasal 3 Undang-Undang No. 20 Tahun 2016 tentang Merek dan Indikasi Geografis

Sebagai akibat dari sistem ketatanegaraan UU Merek dan Indikasi Geografis No. 20 Tahun 2016, pasal ini mengatur bahwa hak merek baru dapat dibentuk setelah pendaftaran. Biarkan orang lain menggunakannya untuk jangka waktu tertentu. Waktu dan mendapatkan perlindungan hukum negara.

2. Pasal 21 ayat (1) huruf b dan c UndangUndang No. 20 Tahun 2016 tentang Merek dan Indikasi Geografis

Pasal ini mengatur bahwa jika merek tersebut merupakan merek terkenal atas pihak lainnya pada komoditas seragam pada prinsipnya atau dalam pengertian umum, dan juga merek terkenal pada produk dan/atau jasa pihak lain tersebut, permohonannya akan ditolak. Atau layanan. Jenis lain yang memenuhi persyaratan tertentu, seperti merek terkenal, dapat dilihat pada penjelasan Pasal 21b(1) UU Merek dan Indikasi Geografis Republik Indonesia Nomor 20 Tahun 2016. -Merek terkenal dari produk dan/atau jasa sejenis milik pihak lain dilakukan di beberapa negara di dunia, dengan mempertimbangkan edukasimasyarakat tentang merek di lini kegiatan yang bersangkutan, yang dilakukan oleh pemiliknya, dan di beberapa negara telah memperoleh sertifikat pendaftaran merek tersebut. Jika ini tidak cukup, Lembaga independen tersebut menerima perintah dari Pengadilan Niaga untuk menyelidiki proses penetapan merek terkenal sebagai dasar penolakan.

3. Pasal 42 Undang-Undang No. 20 Tahun 2016 tentang Merek dan Indikasi Geografis \ Lisensi yurisdiksi yang dimaksud dalam bagian ini adalah lisensi yang diberikan oleh pemilik merek kepada orang lain dengan perjanjian tertulis sesuai dengan peraturan perundang-undangan yang mengatur tentang penggunaan merek dan/atau jasa tersebut.

Dalam hal perlindungan merek terkenal, lisensi pada dasarnya adalah fasilitas perlindungan properti yang 
diberikan oleh undang-undang untuk mencegah orang yang tidak berwenang menyalahgunakan merek terkenal, dan memberikan kebebasan kepada orang tersebut untuk menggunakan mereknya dengan persetujuan pemilik merek. Lisensi merek melakukan fungsi perlindungan ganda atau bilateral, yaitu: pemilik merek (pemberi lisensi) dan orang yang memberikan lisensi (penerima lisensi). (Kurnia \& Darumurti, 2015).

4. Pasal 76 ayat (1) Undang-Undang No. 20 Tahun 2016 tentang Merek dan Indikasi Geografis

Salah satu alasan untuk mengklaim bahwa suatu merek dapat ditarik kembali adalah bahwa merek tersebut pada prinsipnya dan pada hakekatnya sama dengan merek terkenal milik pihak lain tercantum pada Pasal 21(1)(b). Dalam kasus berikut: Perlindungan merek terkenal diberikan dengan segel khusus untuk tanda pembeda. Merek dagang terkenal dapat dilindungi tanpa registrasi terlebih dahulu. Pendaftaran merek di Indonesia dilakukan sesuai dengan sistem konstitutif (pendaftaran bersifat wajib), tetapi apabila ternyata pendaftaran merek tersebut mengandung unsur-unsur yang melanggar integritas, merek terkenal tersebut akan tetap dilindungi. merek dagang terkenal dapat meminta Pencabutan merek dagang.

5. Pasal 83 ayat (1) Undang-Undang No. 20 Tahun 2016 Undang-Undang No. 20 Tahun 2016 tentang Merek dan Indikasi Geografis

Jika Pasal 83 ayat 1 secara jelas mengatur tentang perlindungan merek terkenal berupa ganti rugi dan penangguhan segala kegiatan yang berkaitan dengan merek tersebut, maka dinyatakan sesuai dengan ketentuan merek terkenal. Meskipun merek dagang terkenal tidak terdaftar, dapat diajukan banding ke pengadilan menggunakan perintah pengadilan.

\section{PENERAPAN PERLINDUNGAN MEREK TERKENAL SETELAH BERLAKUNYA UNDANG UNDANG NO 20 TAHUN 2016 TENTANG MEREK DAN INDIKASI GEOGRAFIS}

Adapun kasus-kasus yang akan diuraikan adalah Gudang Garam Vs Gudang Baru, Skyworth Group vs Linawaty Hardjono dan HUGO Boss vs Teddy Tan.

1. Analisis Kasus Gudang Garam vs Gudang Baru Gudang Garam (penggugat) adalah pemilik dan pemegang hak cipta dari logo merek dan variannya, yang terdaftar di Indonesia dan memiliki nomor registrasi sebanyak 79 dalam berbagai kategori barang dan jasa, khususnya dalam melindungi kategori Kretek tipe 34. Rokok Ini telah menjadi merek terkenal dan populer di negara asalnya, Indonesia dan di seluruh dunia. Saat Gudang Baru (terdakwa) menjiplak atau meniru produk Gudan Garam, muncul masalah. Atas dasar ini, Pemohon harus dengan tegas menentang pendaftaran merek Gudang Baru + Lukisan. Atas nama termohon, karena memiliki kesamaan mendasar dengan merek pemohon Gudang Garam yang terdaftar dalam Daftar Umum Merek pada Kantor Kekayaan Intelektual Negara. Pendaftaran merek Gudang+Paint Baru atas nama responden jelas-jelas karena kedengkian (niat tidak jujur), yakni. $\mathrm{H}$ Menyesatkan dan menyesatkan masyarakat. $n$ Merek Gudang Baru + Paint dan produk yang mewakili responden berasal dari pihak pelapor. Kecuali terinspirasi dari penggugat Mark Gudang Garam, sulit membayangkan dari mana asal istilah "Gudang Baru + Lukisan".

Dalam kasus tersebut menghasilkan sebuah putusan judex factie, dalam hal ini adalah Pengadilan Niaga Surabaya yang dimenangkan oleh Gudang Garam. Setelah menerima putusan dari Pengadilan Niaga Surabaya, tergugat mengajukan upaya hukum kasasi ke Mahkamah Agung. Putusan kasasi tersebut ternyata berbalik dengan memenangkan Gudang Baru. Selanjutnya terdapat novum atau bukti baru berupa sebuah putusan pidana yang menyebabkan Gudang Garam mengajukan peninjauan kembali dan dimenangkan oleh pihak Gudang Garam.

Menurut hemat penulis, Putusan yang dijatuhkan oleh Majelis Hakim Peninjauan Kembali telah tepat dalam menerapkan hukum dan secara formil maupun materiil telah sesuai dengan ketentuan perundang-undangan. Sebagaimana pertimbangan-pertimbangan yang diuraikan oleh penulis sebagai berikut:

Majelis Hakim Kasasi keliru dalam menafsirkan ketentuan Pasal 21 ayat (1) huruf a, b dan c Undang-undang Nomor 20 Tahun 2016 TentangMerek Dan Indikasi Geografis yang secara tegas menyebutkan:

Jika merek dagang serupa pada prinsipnya atau secara keseluruhan, aplikasi akan ditolak :

a. "Merek terdaftar milik pihak lain atau dimohonkan lebih dahulu oleh pihak lain untuk barang dan/atau jasa sejenis;

b. Merek terkenal milik pihak lain untuk barang dan/atau jasa sejenis;

c. Merek terkenal milik pihak lain untuk barang dan/atau jasa tidak sejenis yang memenuhi persyaratan tertentu." 
Dalam hal ini menjadi poin penting terkait dengan kebaruan atau bukti baru yang diajukan oleh pemohon untuk diperiksa. Peninjauan kembali ini dilakukan untuk menentukan dan membuktikan bahwa terdakwa P.K. telah divonis pidana tetap dalam perkara Kracht van Gewisde. Secara administratif, hal ini disebabkan oleh status merek tergugat, sebagaimana diatur dalam Pasal 21(3) Undang-Undang Nomor 20 Tahun 2016, jika pemohon mengajukan permohonan merek dengan itikad tidak baik, maka permohonan merek tersebut ditolak. Ada alasan yang masuk akal untuk mencurigai bahwa merek dagang terdaftarnya meniru, menjiplak atau mengejar merek dagang pihak lain untuk kepentingan komersialnya sendiri, menciptakan kondisi persaingan komersial yang tidak sehat, menipu atau menipu konsumen. Merek yang diakui secara umum telah ditiru selama bertahuntahun karena pada dasarnya atau secara substansial mirip dengan merek terkenal. Contoh ini menunjukkan bahwa pemohon memiliki niat jahat, karena setidaknya perlu diketahui bahwa ada faktor-faktor yang dengan sengaja meniru merek terkenal.

Sebagaimana dipertimbangkan oleh Judex Facti sebelumnya bahwa merek "Gudang Baru" beserta variannya didaftarkan oleh Termohon Peninjauan Kembali dengan itikad tidak baik karena membonceng (free- riding) untuk meniru merek Pemohon Peninjauan Kembali yang sudah dikenal luas di masyarakat Indonesia, sehingga hal ini merugikan Pemohon Peninjauan Kembali. Oleh karena itu, demi hukum harus dibatalkan.

2. Analisis Kasus Skyworth vs Linawaty Hardjono

Linawati Harjono mendaftarkan merek dan logo Skyworth ke Kantor Kekayaan Intelektual Negara tanpa persetujuannya, tentu saja penggugat dengan tegas menentang pendaftaran merek SKYWORTH yang tidak sama persis dengan merek tersebut. Dan logo Skyworth penggugat.

Fakta ini dengan jelas menunjukkan bahwa responden memiliki niat jahat atas penyalahgunaan, pemalsuan, dan plagiarisme merek dagang Skyworth yang telah diketahui pemohon di banyak negara. Jadi jika kedua merek ini digunakan secara bersamaan dalam dunia komersial atau retail, pasti akan menimbulkan persaingan. Adalah menyesatkan (menyesatkan) untuk memperlakukan barang yang dibeli konsumen sebagai barang merek Skyworth yang sebenarnya diproduksi oleh penggugat dan barang/jasa asli yang diproduksi oleh penggugat, yang pasti merugikan pemohon.

Dalam hal ini, keputusan Majelis Hakim untuk membatalkan putusan perkara tersebut sudah sesuai dari perspektif hukum yang berlaku menurut pandangan penulis, dan sesuai dengan analisis hukum yang berlaku secara bentuk dan substansi yang penulis uraikan sebagai berikut :

Dalam putusan kasasinya, Judex Juris membatalkan putusan JudexFacti/Pengadilan Niaga pada Pengadilan Negeri Jakarta Pusat, yang menyatakan telah menolak gugatan dan dengan demikian melakukan kesalahan hakim atau kesalahan yang sungguh-sungguh. Putusan Judex Facti/Pengadilan Niaga Pengadilan Negeri Jakarta Pusat adalah benar karena berani melakukan kegiatan peradilan dan melindungi merek terkenal sejenis, meskipun tidak ada ketentuan untuk permohonannya.Karena Indonesia adalah World Trade Organization dan perjanjian TRIPS sebagai lampiran dan Paris. Persetujuan pihak atau penandatangan Konvensi karena itu wajib untuk melindungi merek dagang terkenal, termasuk jenis merek lain, sesuai dengan prinsip perlindungan merek terkenal. Merek dagang terkenal. Merek terkenal di bawah Pasal 6bis Konvensi Paris. Hal itu diperkuat dengan putusan Majelis Hakim Pengawas yang menyatakan bahwa Linawati Harjono telah mengajukan merek/merek jasa dengan itikad tidak baik. Merek Skyworth-RGB di bawah Skyworth.

3. Analisis Kasus Hugo Boss vs Teddy Tan

Ketika Teddy Tan mendaftarkan merek dagang Hugo ke Kementerian Hukum dan Hak Asasi Manusia, dan bahkan dengan sengaja menggunakan merek dagang yang mengandung kata Hugo untuk menjual, mendistribusikan, dan/atau menjual produknya, masalah muncul tanpa lisensi yang pada dasarnya sama. Dan itu milik merek Hugo Boss (dan variasi) sepenuhnya.

Dalam kasus ini, Judex Facti Pengadilan Niaga Pusat Jakarta memutuskan bahwa Teddy Tan menang karena memiliki kuasa khusus atas merek Hugo Boss, sehingga Hugo Boss mengajukan banding terhadap Teddy Tan. Menurut putusan Judex Facti Pengadilan Niaga Pusat Jakarta, Hugo Boss memenangkan kasasi. Judex merek dagang Hugo Boss Judex Facti juga memeriksa detail kesamaan antara merek besar yang sengaja dibuat Teddy Tan dalam merek Hugo yang kontroversial. Merk Hugo Boss (dan variannya) memiliki kemiripan atau kemiripan dengan Teddy Tan. Juga terlihat bahwa juri Judex Facti secara tidak langsung mengenali kesamaan antara merek dagang, terutama melalui unsur kata "Hugo".

Menurut hemat penulis, point ini sangat penting untuk diperhatikan karena menyangkut diterima atau ditolaknya permohonan merek 
berdasarkan Undang-undang Merek. Sebagaimana secara eksplisit dijelaskan pada pasal 20 dan pasal 21 Undang-undang Nomor 20 Tahun 2016 Tentang Merek dan Indikasi Geografis. "Merek tidak dapat didaftar jika tidak memiliki daya pembeda dan Permohonan ditolak jika Merek tersebut mempunyai persamaan pada pokoknya atau keseluruhannya dengan:

a. Merek terdaftar milik pihak lain atau dimohonkan lebih dahulu oleh pihak lain untuk barang dan/atau jasa sejenis;

b. Merek terkenal milik pihak lain untuk barang dan/atau jasa sejenis."

Selain itu, jika pemohon membuat aplikasi dengan itikad buruk, aplikasi akan ditolak. Bahkan, merek dagang "Hugo" yang disengketakan itu didaftarkan oleh Kantor Merek, dalam hal ini Teddy Tan. Oleh karena itu, Judex Judex Facti harus memperbaiki kesalahan tersebut dengan menghilangkan tanda kontroversial tersebut. Penulis percaya bahwa negara harus memperbaiki merek dagang terdaftar. Merujuk pada Pasal 76 Ayat 3 UU Merek. Mengajukan gugatan pembatalan terhadap pemilik merek terdaftar di Pengadilan Niaga.

Keputusan Menteri Hukum dan Hak Asasi Manusia Nomor 67 Tahun 2016 tentang Pendaftaran Merek Pasal 18 ayat 3 mengatur bahwa:

"Dalam menentukan kriteria Merek sebagai Merek terkenal dilakukan dengan mempertimbangkan:

a. Tingkat pengetahuan atau pengakuan masyarakat terhadap Merek tersebut di bidang usaha yang bersangkutan sebagai Merek terkenal;

b. Volume penjualan barang dan/atau jasa dan keuntungan yang diperoleh dari penggunaan merek tersebut oleh pemiliknya;

c. Pangsa pasar yang dikuasai oleh Merek tersebut dalam hubungannya dengan peredaran barang dan/atau jasa di masyarakat;

d. Jangkauan daerah penggunaan Merek;

e. Jangka waktu penggunaan Merek;

f. Intensitas dan promosi Merek, termasuk nilai investasi yang dipergunakan untuk promosi tersebut;

g. Pendaftaran Merek atau permohonan pendaftaran Merek di negara lain."

\section{PENUTUP}

\section{Kesimpulan}

Penerapan perlindungan merek terkenal telah terpenuhi dan terlindungi dengan baik juga sudah sesuai dengan prinsip-prinsip perlindungan hukum merek terkenal yang ada dalam Paris Convention dan Undang Undang No. 20 Tahun 2016. Terdapat catatan yang seringkali terjadi, yaitu kekhilafan hakim yang salah menafsirkan mengenai merekmerek terkenal dan kekhilafan pejabat yang berwenang mengenai pendaftaran beberapa merek yang sudah terpakai atau terkenal di Indonesia maupun negara lain.Perlindungan merek terkenal menurut undang-undang merek di Indonesia

\section{Saran}

Pemerintah harus melakukan upaya serius untuk memastikan bahwa masyarakat, terutama perusahaan komersial, memahami perlindungan hukum merek terkenal. Perlu dilakukan penyaringan lebih ketat terhadap pendaftaran-pendaftaran merek. Perlu adanya sistem yang terintegrasi dan secara otomatis menolak sebuah merek yang diidentifikasi sama dengan merek yang telah terdaftar sebelumnya. Perlu ditingkatkan kemampuan analisis serta teknologi yang memadai untuk pemeriksa merek agar dapat mengidentifikasi merek lebih teliti atau cermat mengingat pentingnya peran Ditjen HKI sebagai pemeriksa merek tersebut.

\section{UCAPAN TERIMA KASIH}

Penulisan mengucapkan terima kasih kepada pihak - pihak yang telah membantu penulis baik memberikan semangat dan memberikan kemudahan dalam pengerjaan skripsi ini.

\section{DAFTAR PUSTAKA}

Ali, Zainudin, 2016, Metode Penelitian Hukum, Jakarta: Sinar Grafika.

Azed, Abdul Bari, 2006, Kompilasi Konvensi Internasional HKI yang

Diratisfikasi Indonesia, Jakarta: Direktorat Jenderal Hak Kekayaan

Intelektual Departemen Hukum dan Hak Asasi Manusia bekerjasama

dengan Badan Penerbit Fakultas Hukum Universitas Indonesia.

Djumhani, Muhammad \& R. Djubaedillah, 2014, Hak Milik Intelektual Sejarah,

Teori dan Prakteknya di Indonesia, Bandung: PT Citra Aditya Bakti.

Endang Purwaningsih, 2005, Hukum Bisnis, Ghalia Indonesia, Jakarta.

Harahap, M. Yahya, 1996, Tinjauan Merek Secara Umum dan Hukum Merek di

Indonesia Berdasarkan Undang-Undang No.19

Tahun 1992, Bandung:

PT. Citra Aditya Bakti. 
Hasibuan, H.D. Effendy, 2003, Perlindungan Merek: Studi Mengenai Putusan

Pengadilan Indonesia dan Amerika Serikat, Jakarta: Program Pasca

Sarjana Fakultas Hukum Universitas Indonesia.

Ibrahim, Johnny, 2006, Teori dan Metodologi

Penelitian Hukum Normatif,

Malang: Bayumedia Publishing.

Indriyanto, Agung \& Irnie Mela Yusnita, 2017, Aspek Hukum Pendaftaran Merek,

Jakarta, Rajawali Press.

Isnaini, Yusran, 2010, Buku Pintar Haki, Bogor:

Ghalia Indonesia.

Jened, Rahmi, 2000, Implikasi Persetujuan TRIPs Bagi Perlindungan Merek di

Indonesia, Surabaya: Yuridika 2015, Hukum Merk Trademark

LAW Dalam Era Global Integrasi

Ekonomi, Jakarta: Prenada Media Group.

Lindsey, Tim, 2003, Hak Kekayaan Intelektual Suatu Pengantar, Bandung:

Alumni

Miru, Ahmadi, 2005, Hukum Merek, Jakarta: PT. RajaGrafindo Persada.

Munandar, Haris \& Sally Sitanggang, 2008, Mengenal Hak Kekayaan Intelektual,

Hak Cipta, Paten, Merek dan Seluk-beluknya, Jakarta: Erlangga.

M. Hadjon, Philipus, 2011, Pengantar Hukum Administrasi Indonesia,

Yogyakarta: Gajah Mada University Press. 95

Hukum Bagi Rakyat Indonesia,

1987, Perlindungan

Surabaya: Bina Ilmu.

Muchsin, 2003, Perlindungan dan Kepastian Hukum Bagi Investor di Indonesia,

Surakarta: Magister Ilmu Hukum Program Pascasarjana Universitas

Sebelas Maret.

Raharjo, Trisno, 1999, Analisis Terhadap Pertimbangan Hukum Hakim Dalam

Putusan-Putusan Perkara Merek Terkenal di Indonesia", Laporan

Penelitian, Yogyakarta: Universitas Muhammadiyah Yogyakarta.

Riswandi, Budi Agus \& M.Syamsudin, 2004, Hak Kekayaan Intelektual dan

Budaya Hukum, Jakarta, PT. Raja Grafindo Persada.

Saidin, OK, 2015, Aspek Hukum Hak Kekayaan Intelektual (Intellectual Property

Rights), Jakarta: PT.Raja Grafindo Persada.
Supramono, Gatot, 2008, Menyelesaikan Sengketa Merek Menurut Hukum

Indonesia, Jakarta: Rineka Cipta.

Titon Slamet Kurnia, 2011, Perlindungan Hukum Terhadap Merek Terkenal di

Indonesia Pasca Perjanjian TRIPs Bandung: Alumni.

Tommy Hendra Purwaka, 2017, Pelindungan Merek Jakarta: Pustaka Obor.

Wibowo, Fauzi, 2017, Hukum Dagang di Indonesia, Yogyakarta: Legality.

PERATURAN PERUNDANG-UNDANGAN :

Undang-Undang Nomor 20 Tahun 2016 tentang

Merek dan Indikasi Geografis,

Lembaran Negara Republik Indonesia Tahun 2016 Nomor 252, Tambahan

Lembaran Negara Nomor 5953.

Paris Convention for the Protection of Industrial Property.

Keputusan Presiden Nomor 15 Tahun 1997 tentang Perubahan Keputusan

Presiden Nomor 24 Tahun 1979 Pengesahan Paris Convention for the

Protection of Industrial Property dan Convention Establishing The World

Intellectual Property Organization.

Peraturan Menteri Hukum dan Hak Asasi Manusia Nomor 67 Tahun 2016, Berita

Negara Republik Indonesia Nomor 2134 Tahun 2016.

96

JURNAL DAN LAIN-LAIN :

Ida Ayu Windhari Kusuma Pratiwi, "Pelanggaran Merek Terkenal Dan

Perlindungan Hukum Bagi Pemegang Hak Dalam Perspektif Paris

Convention, Trips Agreement Dan Uu Merek Indonesia", Jurnal Magister

Hukum Udayana, Vol. 7, No. 3, 2014, hlm. 424.

Thoyyibah Bafadhal, "Perlindungan Hukum terhadap Merek Terkenal di

Indonesia", Jurnal Hukum, Vol. 1, No. 1, 2018, hlm. 28.

Rakhmita Desmayanti, “Tinjauan Umum Perlindungan Merek Terkenal Sebagai

Daya Pembeda Menurut Prespektif Hukum Di Indonesia", Jurnal Cahaya

Keadilan, Vol. 6. No. 1, 2018, hlm. 5.

Nurul Intan Sari Siti, "Perlindungan Hukum Terhadap Merek Terkenal

Berdasarkan Konvensi Paris Dan Perjanjian Trips Serta Penerapannya 
Jurnal Pro Hukum: Vol . 10, No. 2, Desember 2021

Berdasarkan Undang-Undang Nomor 15 Tahun 2001 Tentang Merek",

Jurnal Yuridis, Vol.2 No. 2, 2015, hlm.166.

Frederick W Mosters, "Well-Known and Famous Mark: Is Harmony Possible in

Global Village", Vol. 86, 1996.

Phan Ngoc Tam, "Well-known Trade Mark

Proteciton: A Comperative Study

Between The Law Of Europian Union And

Vietnam" Swedia: Lund

University, 2011.

Admin, Sistem Konstitutif dalam Kepemilikan Hak Atas Merek,

https://optimasihki.id, diakses pada Rabu 25 November 2020, pukul 19.00.

Admin, Penelitian Deskriptif Kualitatif, http://www.informasi-pendidikan.com,

diakses pada Rabu 18 November 2020, pukul 21.00 .

Sufiarina, Hak Prioritas Dan Hak Ekslusif Dalam Perlindungan Hki, Jurnal

Hukum Vol. 3 No.2.

The Paris Convention, http://www.intellogist.com/wiki/The_Paris_Con vention,

diakses tanggal 29 Mei 2021 